\title{
Rationing of work of veterinary specialists serving small domestic, ornamental and wild animals
}

\author{
Ivan N. Nikitin ${ }^{1}$, Elena N. Trofimova ${ }^{1, *}$, Sultan A. Usupov ${ }^{2}$, and Natalia A. Nikiforova ${ }^{1}$ \\ ${ }^{1}$ Kazan State Academy of Veterinary Medicine named after N. E. Bauman, Kazan, 420029, Russia \\ ${ }^{2}$ Federal center for Toxicological, radiation and biological safety, Kazan, Scientific town-2, 420075, Russia
}

\begin{abstract}
Veterinary specialists have been rationing the work in the Russian Federation for more than 60 years. During this period, a lot of material has been accumulated on the development of scientific, methodological and regulatory problems. Recommendations on the regulation of labor of specialists in the field of veterinary medicine have been developed and approved: the time standards for the implementation of anti-epizootic, treatment-and-prophylactic, veterinary-sanitary measures for servicing cattle, pigs, horses, sheep, birds; diagnostic tests carried out by veterinary laboratories, and veterinary and sanitary examination of animal and vegetable products as well. The market of veterinary services in the cities of our country requires the expansion of the list of veterinary services in the field of servicing small domestic, decorative, exotic and wild animals. The article presents: features of the regulation of labor of veterinary specialists; classification of veterinary work depending on their direction, labor capacity, significance for ensuring epizootic well-being; norms of time for performing about 300 types of veterinary work when servicing small pets, 35 wild animals, 32 decorative and exotic animals. The established norms of labor costs for the implementation of veterinary measures in small domestic, decorative, exotic and wild animals will be used for: analysis of personnel support for veterinary institutions; planning their staffing levels; studying the effectiveness of the use of labor resources; establishing reasonable prices for paid veterinary work; determination of reserves for increasing labor productivity of veterinary specialists.
\end{abstract}

\section{Introduction}

Working hours are traditionally seen as a matter of collective bargaining or managerial decision making. Properly planned working time and rest time allows the employer and employee to effectively use both working time and rest and vacation time [1]. Time boundaries of work are lines that separate work from rest and paid work from unpaid work [2]. The effective use of working time contributes to the regulation of labor.

The first attempts to standardize the labor of veterinary specialists were made in the sixties of the $\mathrm{XX}$ century. Basic research was carried out in the seventies and eighties at the Kazan Veterinary Institute named after N.E. Bauman, All-Union Scientific and Control Institute of Veterinary Medicines, All-Union Scientific and Research Institute of Non-communicable Diseases. Based on the results of these studies, a methodology for standardizing the work of veterinary specialists was developed, and labor standards for veterinarian specialists at medical and preventive and diagnostic veterinary institutions were established.

The issues of labor standards for veterinary specialists are included in the curricula for the training of veterinarians and paramedics, published in textbooks and monographs. Recommendations on the standardization of labor of veterinary specialists approved by the
Scientific and Technical Council of the Ministry of Agriculture of the Russian Federation and the Association of Practicing Veterinarians of the Russian Federation have been developed, and standard time standards have been established [3-7].

The market of veterinary work (services) in the cities of the Russian Federation is systematically changing. The market demand for veterinary services for farm animals is reduced, and the demand for services for small domestic, exotic, decorative and wild animals is increasing. Accordingly, there is a narrow specialization of veterinarians in surgeons, oncologists, anesthetists, ophthalmologists, dermatologists, herpetologists, rodentologists, ornithologists, etc. In this regard, the time standards for veterinary specialists to carry out veterinary work established in the last century are outdated and do not meet the requirements of modern all-Russian and regional markets.

This article summarizes the results of standardization of labor by veterinary specialists serving small domestic, wild, decorative and exotic animals.

\section{Materials and methods}

Scientific research in the regulation of labor for small pets was carried out on the basis of state veterinary institutions and private veterinary clinics in Moscow, St. Petersburg,

* Corresponding author: alenatro@mail.ru 
Kazan, Samara, Kirov, Izhevsk, Yoshkar-Ola, Cheboksary, Novocheboksarsk, Naberezhnye Chelny.

Studies on the regulation of labor of veterinary specialists serving decorative and exotic animals were carried out in state and private veterinary institutions, as well as in places where these animals are kept in the cities of Cheboksary, Kazan, Moscow, St. Petersburg, Vitebsk and Minsk. The labor standards of veterinarians serving wild animals kept in zoological parks and circuses were carried out in specialized cultural institutions in the cities of Kazan, Moscow, Izhevsk, and Nizhny Novgorod.

The study of the costs of working time for veterinary care of small domestic, wild, decorative and exotic animals was carried out taking into account the following normative factors: the efficiency and safety of the use of veterinary equipment and instruments; the latest methods of veterinary manipulation; features of veterinary manipulations in various species of animals and birds; age of animals, and their physiological state; the individual nature of the ongoing veterinary activities and their diversity; conditions for keeping, feeding and caring for animals; methods for performing veterinary measures; technical equipment of veterinary institutions with modern veterinary facilities; means and safety measures and health protection of veterinary specialists; specialization and qualification level of veterinary specialists; social and sanitary-hygienic working conditions.

When developing labor standards, the following rules were taken into account: the unity of the norms of working time costs when performing similar types of veterinary work in the same conditions; the optimality of labor costs in veterinary services; efficient use of the cost of working time when performing veterinary work; updating labor input standards, taking into account the improvement of veterinary technology.

Veterinary works performed when servicing wild, ornamental and exotic animals were classified according to their direction, labor intensity, significance to ensure the welfare of zoos, circuses and other habitats for infectious diseases, operational diagnosis, prevention and elimination of diseases and treatment of sick animals.

These include: methods of immobilization of animals and birds; maintaining a protocol of immobilization, monitoring of anesthesia; methods for the identification and labeling of animals; systematic observation of animals, processing of records of veterinary manipulations; registration and storage of animal clinical examination data; observation of the dynamics of the condition during a subsequent clinical examination; planning and implementation of antiepizootic, medical and preventive, veterinary and sanitary measures; group and individual inspection of animals; identification, isolation and treatment of sick animals; examination of animals before transportation; monitoring compliance with the requirements of veterinary legislation, veterinary rules for their feeding and maintenance.

When developing standards for the maintenance of animals, the number of manipulations and the importance of their implementation were taken into account. In particular, this applies to diagnostic tests for animals and birds that can transmit an infectious disease to humans [8]. The success of treatment and the number of injured people and animals depends on how quickly and correctly the diagnosis is made [9].

\section{Research results}

Instrumental research methods and laboratory diagnostics occupy an important place in the daily work of a veterinary institution receiving small pets. A modern veterinary clinic can carry out a wide range of laboratory studies of biomaterials from animals and functional diagnostics of the state of an animal's body.

Table 1. Standards of time for the diagnosis of diseases of small pets

\begin{tabular}{|c|c|}
\hline Name of veterinary work & $\begin{array}{c}\text { Time norms } \\
{[\mathrm{min}], \mathrm{M} \pm \mathrm{m}}\end{array}$ \\
\hline $\begin{array}{l}\text { Venous blood sampling for laboratory } \\
\text { testing: } \\
\text { - dogs } \\
\text { - cats }\end{array}$ & $\begin{array}{l}6.0 \pm 0.23 \\
6.8 \pm 0.31\end{array}$ \\
\hline Capillary blood sampling & $5.2 \pm 0.16$ \\
\hline General blood analysis & $41.3 \pm 1.24$ \\
\hline $\begin{array}{l}\text { Hematological examination on an } \\
\text { automatic blood analyzer ( } 22 \text { indicators) }\end{array}$ & $23.2 \pm 0.2$ \\
\hline Sali determination of hemoglobin & $4.5 \pm 0.22$ \\
\hline $\begin{array}{l}\text { Hemoglobin testing with a Hemo-control } \\
\text { analyzer }\end{array}$ & $7.9 \pm 0.34$ \\
\hline Rapid blood test for glucose (glucometry) & $5.5 \pm 0.18$ \\
\hline Biochemical blood test (complete) & $67.7 \pm 1.2$ \\
\hline $\begin{array}{l}\text { EIA for viral diseases: } \\
\text { - single } \\
\text { - batch (10 samples })\end{array}$ & $\begin{array}{l}75.5 \pm 2.3 \\
111.0 \pm 3.8\end{array}$ \\
\hline $\begin{array}{l}\text { PCR with electrophoretic detection (20 } \\
\text { samples), including } 1 \text { sample: } \\
\text {-for PCR diagnostics of viral infections } \\
\text { (DNA viruses) } \\
\text { - for PCR diagnostics of viral infections } \\
\text { (RNA viruses) }\end{array}$ & $\begin{array}{l}20.5 \pm 0.5 \\
24.0 \pm 0.6\end{array}$ \\
\hline General urine analysis & $35.7 \pm 1.05$ \\
\hline Macroscopic examination of feces & $3.5 \pm 0.07$ \\
\hline Microscopic examination of feces & $20.0 \pm 0.87$ \\
\hline Mycological examination of feces & $8.1 \pm 0.35$ \\
\hline Chemical study of feces & $44.9 \pm 1.31$ \\
\hline $\begin{array}{l}\text { Cytological examination: } \\
\text { - finished smear imprint } \\
\text { - liquid material (urine, blood, exudate) }\end{array}$ & $\begin{array}{l}22.0 \pm 0.32 \\
24.0 \pm 0.61\end{array}$ \\
\hline $\begin{array}{l}\text { Ultrasound of the abdominal organs in } \\
\text { small pets (dog, cat) (observational) }\end{array}$ & $30.9 \pm 1.37$ \\
\hline $\begin{array}{l}\text { X-ray examination of small domestic } \\
\text { animals and birds (using a digital X-ray } \\
\text { machine) }\end{array}$ & $27.0 \pm 0.58$ \\
\hline $\begin{array}{l}\text { ECG (electrocardiogram) of small domestic } \\
\text { animals (without interpretation) }\end{array}$ & $20.1 \pm 0.6$ \\
\hline Ophthalmoscopy (direct) & $14.6 \pm 0.26$ \\
\hline Eye tonometry & $5.7 \pm 0.05$ \\
\hline Calposcopy of females of small pets & $9.3 \pm 0.43$ \\
\hline Diagnostic cystocentesis & $9.2 \pm 0.17$ \\
\hline $\begin{array}{l}\text { Endoscopic examination of the esophagus } \\
\text { and stomach }\end{array}$ & $46.5 \pm 2.33$ \\
\hline Endoscopic examination of the nasal cavity & $26.7 \pm 1.5$ \\
\hline
\end{tabular}


Information about the individual labor standards of veterinary specialists for laboratory research of biomaterials from small pets and instrumental research methods are presented in Table 1.

From table 1 it is seen that the most time-consuming are a complete biochemical blood test, a general analysis of blood, urine, a chemical study of feces. It should be noted that a veterinarian spends almost 7 times more time on a single EIA test for viral diseases than with a simultaneous study of more than 10 samples. The same is true for PCR studies with electrophoretic detection. The simultaneous study of a larger number of samples allows the veterinarian to use the time spent most effectively. Less time is spent on research of one indicator: macroscopic examination of feces, rapid analysis of blood for glucose.

Labor costs for a survey ultrasound examination of the abdominal organs in an unproductive animal is 30.9 minutes; 27.0 minutes for X-ray examination using a digital X-ray machine; 20.1 minutes for electrocardiogram without taking into account the time of the veterinarian spent on interpretation of the electrocardiogram. Currently, in veterinary practice, endoscopic examinations are widely used. For example, the norms of labor costs for endoscopic examination of the esophagus and stomach are 46.5 minutes and 26.7 minutes. The listed types of instrumental research methods are rather laborious and require special training of animals and equipment from veterinary specialists.

Table 2 presents some norms of time spent by veterinarians when receiving small pets, carrying out preventive measures, various medical procedures and surgical operations.

The most time-consuming are surgical operations cesarean section of a female dog or a cat. Consequently, the time spent directly depends on the breed of the female. The larger the bitch, the more time is spent on the operation. The conservative treatment of the fracture with the application of an immobilizing bandage (56.8 minutes), castration of a male (50.9 minutes), and a cat (30.3 minutes) are quite laborious manipulations. Less laborious is the amputation of rudimentary phalanges of the fingers of a puppy up to 20 days of age (20.5 minutes). It should be especially noted that all ongoing surgical procedures and operations require careful preoperative preparation, accompanying the animal during the operation, and withdrawal from anesthesia.

A veterinarian will spend 20.0 minutes on a clinical examination of an animal with an initial diagnosis, repeated administration of an animal during treatment and treatment adjustment (15.5 minutes), preventive examination of an animal with consultation with the owner (12.6 minutes), initial vaccination (14.4 minutes), preventive deworming with consultation with the owner animal (10.3 minutes), examination of the animal for fungal diseases and the issuance of certificates (11.2 minutes).

After the initial reception, diagnostic tests, the veterinarian prescribes treatment for the animal. The treatment of sick animals consists of many procedures of various complexity. So, the most commonly used methods of treating animals are oral administration of a drug (4.0 minutes), rectal (vaginal) administration (3.6 minutes), subcutaneous (intramuscular) injection (2.5 minutes), intravenous jet administration of drugs (6.5 minutes, the average volume of injected medicinal solutions is $20 \mathrm{ml}$ ).

If you need regular intravenous administration of medicinal solutions into the peripheral veins of the animal, an intravenous catheter is installed (6.3 minutes). For therapeutic purposes, as well as for local anesthesia, various novocaine blockades are widely used. So, the norm of time for circular novocaine blockade is 10.8 minutes, supopleural blockade of the celiac nerves according to V.V. Mosin takes 19.7 minutes A veterinary specialist spends 9.0 minutes on lavage of the auricles with non-purulent otitis, 24.2 minutes for cleaning enema after poisoning or viral infections, 14.3 minutes for milkfang extirpation, 10.2 minutes for claw prophylaxis.

Table 2. Standards of time for the reception, prevention and treatment of diseases of small pets

\begin{tabular}{|c|c|}
\hline Name of veterinary work & $\begin{array}{c}\text { Time norms } \\
{[\mathrm{min}], \mathrm{M} \pm \mathrm{m}}\end{array}$ \\
\hline $\begin{array}{l}\text { Clinical examination of the animal with the } \\
\text { initial diagnosis }\end{array}$ & $20.0 \pm 0.64$ \\
\hline Repeated clinical examination of the animal & $15.5 \pm 0.29$ \\
\hline Inspection of animal with consultation of owner & $12.6 \pm 0.47$ \\
\hline Vaccination (primary) & $14.4 \pm 0.35$ \\
\hline $\begin{array}{l}\text { Preventive deworming with consultation of the } \\
\text { owner of the animal }\end{array}$ & $10.3 \pm 0.18$ \\
\hline $\begin{array}{l}\text { Inspection of the animal for fungal diseases and } \\
\text { the issuance of a certificate }\end{array}$ & $11.2 \pm 0.25$ \\
\hline Oral administration of drugs & $4.0 \pm 0.11$ \\
\hline Rectal or vaginal administration of drugs & $3.6 \pm 0.05$ \\
\hline $\begin{array}{l}\text { Preparation and subcutaneous (intramuscular) } \\
\text { injection of the drug }\end{array}$ & $2.5 \pm 0.05$ \\
\hline $\begin{array}{l}\text { Intravenous catheter placement (in peripheral } \\
\text { veins) }\end{array}$ & $6.3 \pm 0.16$ \\
\hline Intravenous injection & $6.5 \pm 0.26$ \\
\hline Lavage of the auricles & $9.0 \pm 0.14$ \\
\hline $\begin{array}{l}\text { Setting a cleansing enema (poisoning, viral } \\
\text { infections) }\end{array}$ & $24.2 \pm 0.82$ \\
\hline Circular novocaine blockade & $10.8 \pm 0.37$ \\
\hline $\begin{array}{l}\text { Suppleural blockade of the celiac nerves (V.V. } \\
\text { Mosin method) }\end{array}$ & $19.7 \pm 0.78$ \\
\hline $\begin{array}{l}\text { Caesarean section of a female: } \\
\text { small breeds } \\
\text { medium breeds } \\
\text { large breeds }\end{array}$ & $\begin{array}{l}90.5 \pm 2.5 \\
111.0 \pm 5.0 \\
140.5 \pm 7.0\end{array}$ \\
\hline Cesarean section of a cat & $86.8 \pm 3.17$ \\
\hline Castration of a cat & $30.3 \pm 0.8$ \\
\hline Male dog castration & $50.9 \pm 1.23$ \\
\hline $\begin{array}{l}\text { Conservative treatment of a fracture with an } \\
\text { immobilizing dressing }\end{array}$ & $56.8 \pm 2.8$ \\
\hline $\begin{array}{l}\text { Amputation of rudimentary phalanges of a } \\
\text { finger to a puppy from the age of } 14 \text { days to } 2 \\
\text { months }\end{array}$ & $7.6 \pm 2.18$ \\
\hline Extirpation of a baby tooth (fang) & $14.3 \pm 0.6$ \\
\hline Preventive claw trimming & $10.2 \pm 0.42$ \\
\hline
\end{tabular}

Long-term studies of the activities of veterinary specialists serving small pets have established: 
- 115 standards for admission and laboratory research of biomaterials in the conditions of state veterinary institutions and private clinics;

- 38 standards for antiepizootic measures;

- 40 standards for animals and clinical diagnosis of diseases;

- 57 norms for treatment (therapeutic procedures);

- 50 standards for obstetric, gynecological, surgical and cosmetic procedures, totaling 300 time standards.

Standards of time for the implementation of individual veterinary work in the maintenance of wild, decorative and exotic animals are presented in Table 3.

Table 3. Standards of time for veterinary work in the treatment of wild, decorative and exotic animals

\begin{tabular}{|l|c|}
\hline \multicolumn{1}{|c|}{ Name of veterinary work } & $\begin{array}{c}\text { Time norms } \\
{[\mathrm{min}], \mathrm{M} \pm \mathrm{m}}\end{array}$ \\
\hline Immobilization of a bear, maral & $38.2 \pm 1.02$ \\
\hline $\begin{array}{l}\text { Intramuscular administration of an } \\
\text { analgesic drug to serval, hyena }\end{array}$ & $30.2 \pm 0.51$ \\
\hline $\begin{array}{l}\text { Clinical examination of animals: } \\
\text { - foxes, sable } \\
\text { - wolf, primate }\end{array}$ & $23.8 \pm 0.23$ \\
\hline X-ray examination of charza & $26.8 \pm 0.7$ \\
\hline Ultrasound of the abdomen of the tiger & $28.7 \pm 0.8$ \\
\hline Taking blood from a deer, elk & $67.2 \pm 1.32$ \\
\hline Monkey Rabies Vaccination & $37.6 \pm 1.03$ \\
\hline $\begin{array}{l}\text { Vaccination against plague, leptospirosis, } \\
\text { adenovirus, coronovirus infections of the } \\
\text { fox, wolf }\end{array}$ & $29.9 \pm 1.17$ \\
\hline Deworming group method of reptiles & $24.9 \pm 1.73$ \\
\hline $\begin{array}{l}\text { Intramuscular injection to a large and } \\
\text { medium-sized parrot }\end{array}$ & $2.9 \pm 0.15$ \\
\hline Intravenous catheter placement to a rabbit & $6.0 \pm 0.17$ \\
\hline Ferret vaccine complex vaccine & $14.5 \pm 0.35$ \\
\hline $\begin{array}{l}\text { Vaccination of a rabbit with a complex } \\
\text { vaccine against infections }\end{array}$ & $13.5 \pm 0.33$ \\
\hline Deworming of a rabbit & $7.0 \pm 0.25$ \\
\hline Treatment of a raccoon from ectoparasites & $5.3 \pm 0.2$ \\
\hline Tortoise deworming & $8.0 \pm 0.31$ \\
\hline $\begin{array}{l}\text { Microscopy of a native smear of bird } \\
\text { droppings }\end{array}$ & $5.7 \pm 0.3$ \\
\hline $\begin{array}{l}\text { Taking blood from a large, medium-sized } \\
\text { parrot }\end{array}$ & $8.9 \pm 0.4$ \\
\hline Blood collection from chinchilla & $10.1 \pm 0.26$ \\
\hline Castration of a rabbit & $20.8 \pm 0.3$ \\
\hline Rat ovariohysterectomy & $26.7 \pm 0.78$ \\
\hline $\begin{array}{l}\text { Cutting of incisors, premolars and molars } \\
\text { with a dental drill for a rabbit }\end{array}$ & \\
\hline
\end{tabular}

The most time-consuming work for servicing wild animals is taking blood samples from a deer (moose); less labor-consuming is immobilization of a bear (maral), vaccination against plague, leptospirosis, adenovirus, coronovirus infection of a fox (wolf), vaccination of a monkey against rabies. Standards of time for one procedure in the range of 23.8-30.2 minutes were established for intramuscular administration of an analgesic drug to serval (hyena), a clinical examination of a fox (sable, wolf, primate), X-ray examination of harza, ultrasound examination of the organs of the abdominal cavity of the tiger, deworming of reptiles.

When treating both decorative and exotic animals, the most labor-intensive labor processes are rat ovariogysteroectomy; trimming of incisors, premolars and molars with a dental drill to a rabbit; castration of a rabbit; less labor-intensive are vaccination of a ferret (rabbit) with a complex vaccine; taking blood from a chinchilla. The lowest time standards were set for intramuscular injection of a parrot, placement of an intravenous catheter for a rabbit, deworming of a turtle, rabbit, treatment of a raccoon from ectoparasites, microscopy of a native smear of bird droppings, blood collection from a large, medium-sized parrot.

Studies of the activities of veterinary professionals serving wild animals in zoos, circuses, private homes and their natural habitats have established:

- 11 norms of time for admission and clinical diagnosis;

- 8 standards for laboratory research of biomaterials;

- 11 standards for antiepizootic measures;

- 5 standards for treatment, medical and surgical procedures, totaling 35 standards.

Based on the materials of the timing of labor processes when servicing decorative and exotic animals, the time standards for performing veterinary work have been established:

- 7 norms of time for laboratory research of biomaterials from different species of animals (parrots, rabbits, turtles, rodents);

- 11 norms of time for surgical interventions;

- 6 norms for antiepizootic measures;

- 10 norms for treatment (therapeutic procedures);

- 5 standards for obstetric, gynecological, surgical and cosmetic procedures, totaling 32 time standards.

\section{Conclusion}

Long-term studies have established standard norms for the time it takes to carry out veterinary work when servicing small pets, which are published in textbooks, manuals, monographs. They are systematically refined and improved. Typical and individual norms of time for performing veterinary measures when servicing small domestic, decorative, exotic and wild animals in zoos, circuses, private and apartment buildings, as well as in their natural habitat, can significantly improve veterinary services, more effectively carry out antiepizootic, therapeutic and preventive actions.

The established norms of labor costs for the implementation of veterinary measures among small domestic, decorative, exotic and wild animals will be used for:

- analysis of staffing of public and private veterinary institutions;

- planning staffing levels of veterinary institutions;

- study of the efficiency of use of labor resources of the state, cooperative and private veterinary services and institutions;

- establishment of scientifically based amounts of financial support for the implementation of state tasks of institutions of the State Veterinary Services;

- establishment of reasonable prices for paid veterinary work (services); 
- determination of reserves for increasing labor productivity of veterinary specialists.

\section{References}

1. A.C.L. Davies, University of Oxford, pp. 97-117 (Cambridge University Press, 2010) DOI: https://doi.org/-10.1017/CBO9780511626968.007

2. G. Patmore, G. Michelson, University of Sydney, pp. 21-38 (Cambridge University Press, Sydney, 2012) DOI: https://doi.org/10.1017/CBO9780511814624.003

3. Recommendations on the regulation of labor of veterinary specialists, Approved by the NTS Ministry of Agriculture of the Russian Federation as of 26 December 2014, 54 p. (2014)
4. Recommendations on the regulation of labor of veterinary specialists in the service of small pets, Approved by the Association of Practicing Veterinarians of the Russian Federation as of 16 May 2012, 29 p. (2012)

5. Typical standards and norms of time for veterinary work on state farms and collective farms, $25 \mathrm{p}$. (1989)

6. I.N. Nikitin, Res. J. of pharmac., boil. and chem. sci., 10(1), 1781-1787 (2019)

7. E.N. Trofimova, Issues of regul. and legal regulat. in veter. med., 1, 30-35 (2011)

8. L.G. van Hilten, From bird flu to malaria: open access J. takes holistic approach to disease control, Elsevier® J, Finder 15-18 (2016)

9. J. Mayer, T.M. Donnelly, Clin. Veter. Advisor: Birds and Exotic Pets, 1, 784 (2013) 